\title{
Development and validation of modules improving self- awareness excellent services of academic staff
}

\author{
Taufik Taufik $^{\left.1^{*}\right)}$, Rima Pratiwi Fadly ${ }^{2}$, Yola Eka Putri ${ }^{3}$ \\ ${ }^{123}$ Universitas Negeri Padang, Indonesia \\ *)Corresponding author, ఏe-mail: taufik@konselor.org
}

\begin{abstract}
The purpose of this study was to increase self-awareness of education personnel and help them offer excellent service to students in the university. It aims to: (1) describe the module design to increase self-awareness of excellent service for education personnel (2) perform module validation tests and (3) conduct module reliability tests. The study used the Research and Development (R\&D) method. It was descriptive and involved four experts and 12 education staff at Universitas Negeri Padang as the subjects. The instruments used include (1) Validity Testing Instruments Module Contents (2) Ifdil \& Taufik Self-Awareness Inventory and (3) Module Instruments. The results show that Self-Awareness Improvement Module for Excellent Services Education Personnel can be accepted and be used in selfawareness programs for the staff.
\end{abstract}

Keywords: Modul, self-awareness, excellent services, education personnel

How to Cite: Taufik, T., Fadli, R., \& Putri, Y. (2019). Development and Validation of Modules Improving Self-Awareness Excellent Services of Education Personnel. Couns-Edu: International Journal of Counseling and Education, 4(3): pp. 94-101. DOI: https://doi.org/10.23916/0020190421330

This is an open-access article distributed under the Creative Commons Attribution License, which permits unrestricted use, distribution, and reproduction in any medium provided the original work is properly cited. (C2019 by author.

\section{Introduction}

Education personnel refers to members of the community devoted and appointed to support the implementation of education (Lestari, 2011; Mamulati, Triyuwono, \& Mulawarman, 2016; Ningrum, 2016; Rahman, 2010; Sholeh, 2013). They are responsible for carrying out administration, management, development, supervision and technical services to support the education process in education units (Danumiharja, 2014; R. Septiana, 2013; Susongko, 2016). Education personnel has an important role in the proper implementation of the education process. To effectively achieve this objective, they need emotional intelligence. Generally, emotional intelligence impacts work commitment and have the potential to improve the work performance of education personnel (Efendi, 2013; Supriyanto \& Troena, 2012; Yudhaningsih, 2011).

Self-awareness is an aspect of emotional intelligence and people with this ability recognizes their emotions (Daud, 2012; Yuniani \& Pamudji, 2010). However, it is not easy to determine whether someone has self-awareness. The ability to monitor feelings regularly is important for psychology and selfunderstanding in work or education personnel (Rahmasari, 2016). Self-awareness is the ability to know what you feel inside and use it to guide your decision making, have realistic benchmarks for abilities and strong self-confidence (Gipps, 2002). A person can understand the various potentials in him regarding the strengths they have and their weaknesses (Nguyen et al., 2016). 
People with high self-awareness 1) understand their strengths, weaknesses, values, and motives; 2) measure mood and understand how it affects others, 3) receive feedback from others on how to improve; 4) able to work even under uncertainty; 5) show a sense of humor; 6) understand various factors that make them liked; and 7) use pressure on members of the organization (Chow, 2019; Xu \& Chan, 2017). Therefore, individuals with high self-awareness have strengths and weaknesses.

Self-awareness is nothing more than a perception of the inner mental state of the subject. Based on the timeframe, there are three levels of self-awareness. The first one arises after the release of emotion (Rifani, 2016). The second one arises when we feel something emotionally while the third one comes before we do anything (Prastika, 2016). To reach a stage of self-awareness, people need experience and social interaction (Rusuliana, 2015; N. Z. Septiana, 2016). A person can express thoughts, feelings, ideas, or resentment to others to receive attention or feedback.

Self-awareness is very important in improving service quality. According to (Taufik, Ifdil, \& Netrawati, 2017), officers with self-awareness tend to improve the quality of service as indicated by the customers' satisfaction. Service quality improvement can be achieved in case there is an employee's selfawareness of the services provided. However, the same study indicated that only $28.7 \%$ of respondents had high self-awareness. For this reason, this study carried out the development and validation of the module to increase self-awareness excellent service of education personnel. This module could be used as one of the guidelines for education personnel to train themselves and increase self-awareness.

\section{Method}

This study was conducted using a development research design in education (Anderson \& Shattuck, 2012; Buchori et al., 2017; Richey \& Klein, 2014). Research and Development (R\&D) method was used (Day, Fleenor, Atwater, Sturm, \& McKee, 2014; McDonough \& McDonough, 2014; Mead, 2017; Richey \& Klein, 2014). This study specifically aims to (1) describe the module design to increase self-awareness of the prime service of teaching staff (2) conduct a module validation test and (3) carry out a module reliability test. To validate the contents of the module, four experts were selected, and to test the validity and reliability of items, individual experiments were carried out on 12 education staff at Padang State University. The instruments used include (1) Instrument Content Validity Test Instrument (2) Ifdil \& Taufik Self Awareness Inventory and (3) Instrument Reliability Module. Data were analyzed by the Wilcoxon Test. The results showed the Self Awareness Improvement Module for the Best Service Education Personnel was acceptable and could be used in self-awareness programs for education staff in service provision. Analysis of the data used is descriptive, to illustrate the feasibility of the module according to the expert.

\section{Result and Discussion}

\section{Self-awareness module design}

This is the structure used to make guidance for facilitators to use and improve their knowledge, competencies, and skills in carrying out exercises that improve and optimize the self-awareness of education personnel. This module discusses aspects that need to be improved, including procedures and efforts to develop skills, increase knowledge and advanced training. It can be used by facilitators to develop and improve participants' insights and knowledge and skills to have self-awareness and offer excellent services. All the necessary materials are contained in this module with 7 items and 23 activities.

Coaching Module Improvement of self-awareness Excellent Service Educational Staff comprises seven sub-modules. This includes Self Awareness, Belief on Self Ability, Optimistic, Aim, Responsible, Rational and Realistic, and Skill. Each of the seven sub-modules has objectives and activities along with the steps to be followed. This includes;

\section{Stage 1: self awareness}

Self Awareness is a module that emphasizes individual understanding of the aspects possessed, such as selfhood, knowledge, and skills to be optimized to provide an excellent service for education personnel. 


\section{Stage 2: Confidence in Yourself}

Self-confidence is related to self-efficacy, which means an individual's subjective beliefs to be able to overcome various problems or tasks and carry out activities oriented towards achieving the desired goals (Rustanto, 2017)

Table 1. Module Items

\begin{tabular}{l} 
Nome of Activity \\
\hline Excellent Service Concept \\
Ikhlas work \\
Who am I \\
Tips to Become an Attractive Person \\
Become a Beneficial Person \\
Working is Worship \\
I can do it \\
Positive thinking \\
Work Reflects Me! I Reflected Work \\
Results! \\
Work sincerely, work smart
\end{tabular}

Change or Die?

Impossible is Nothing

\section{Primaku Service}

Soul Art Serving

Let's open

Stop Gratification, Corruption, Collusion, and Nepotism

Totality

Money is not everything

Helps That Worship

Risk of Part of Work

Stop Complain

Serving is beautiful

ACT

Miracle Words

Look at me

Smile Exercise

3M

Soft Skill

\begin{tabular}{|c|c|}
\hline & \\
\hline $\begin{array}{l}\text { Increasing self-awareness of education personnel } \\
\text { to optimize work }\end{array}$ & 60 minutes \\
\hline $\begin{array}{l}\text { Increase self-awareness of education personnel to } \\
\text { provide excellent service }\end{array}$ & 60 minutes \\
\hline $\begin{array}{l}\text { Increasing sincerity in education personnel in } \\
\text { daily life and specifically working }\end{array}$ & 60 minutes \\
\hline $\begin{array}{l}\text { Improve the skills of participants to increase self- } \\
\text { awareness }\end{array}$ & 60 minutes \\
\hline $\begin{array}{l}\text { Improve the skills of participants to increase self- } \\
\text { awareness }\end{array}$ & 60 minutes \\
\hline $\begin{array}{l}\text { Improve the skills of participants to increase self- } \\
\text { awareness }\end{array}$ & 60 minutes \\
\hline elf-awareness of education personnel & 60 minutes \\
\hline Incre & 60 minutes \\
\hline $\begin{array}{l}\text { Increase optimism of education staff with positive } \\
\text { thinking }\end{array}$ & 60 minutes \\
\hline $\begin{array}{l}\text { Improve the skills of educators to do work as a } \\
\text { form of identity }\end{array}$ & 60 minutes \\
\hline $\begin{array}{l}\text { Improve the skills of education personnel to } \\
\text { understand and implement honesty and work } \\
\text { smart }\end{array}$ & 60 minutes \\
\hline $\begin{array}{l}\text { Improve participants 'skills to arouse confidence } \\
\text { to work well }\end{array}$ & 60 minutes \\
\hline $\begin{array}{l}\text { Improving participants' skills to analyze } \\
\text { conditions in work and think nothing is } \\
\text { impossible to spur good performance in work }\end{array}$ & 60 minutes \\
\hline $\begin{array}{l}\text { Improve the skills of participants to work with } \\
\text { excellent service to increase performance and } \\
\text { professionalism }\end{array}$ & 60 minutes \\
\hline $\begin{array}{l}\text { Improve participants' skills related to art in } \\
\text { serving as educators }\end{array}$ & 60 minutes \\
\hline $\begin{array}{l}\text { Increase self-awareness of education personnel to } \\
\text { be objective in an open way to work }\end{array}$ & 60 minutes \\
\hline Increasing self-awareness of education personnel & 60 minutes \\
\hline
\end{tabular}

to be more objective by avoiding acts of gratuity, corruption, collusion, and nepotism in work Increase self-awareness of education personnel to be more objective by building attitudes of totality in work

Increase self-awareness on the basis and responsibilities of work and not for money alone Increase self-awareness for the need for sincerity and altruism in work

Increase self-awareness that every job has certain risk consequences that need to be understood Increase participants' understanding of stopping complaints

Improve the skills of participants in serving Improve the skills of participants related to ACT Boost participants' skills in using miracle words Improve participants' skills in attracting positive attention

Enhance the skills of participants in smiling Increase participants' understanding of $3 \mathrm{M}$ Improve and develop soft skills so that
60 minutes

60 minutes

60 minutes

60 minutes

60 minutes

60 minutes 60 minutes 60 minutes 60 minutes

60 minutes

60 minutes 60 minutes 
participants can take on the role of a professional reliable in technical matters and very skillful in dealing with others

Eye contact

Improve and understand the language conveyed

60 minutes by others through eye contact

\section{Stage 3: Optimistic}

Optimism is a module that emphasizes the belief in everything in terms of good and pleasant and always has positive expectations in everything that provides service.

\section{Stage 4: Objective}

The objective is a module that emphasizes a person's positive attitude in dealing with a situation. Objective attitudes can be seen from one's habits in expressing things as they are without personal feelings (Anwar, 2009).

\section{Stage 5: Responsible}

Responsible is a module that emphasizes the development of individual attitudes and characters to bear compensation and risk from each step or decision taken.

\section{Stage 6: Rational and Realistic}

This module emphasizes being rational and realistic. Based on KBBI, rational means according to the mind and logical considerations; a healthy mind; and fit with reason. Rational involves making consistent choices and maximizing values within certain limits while real means natural (Pricila, Ulfah, \& Basri, 2013).

\section{Stage 7: Skill}

This module emphasizes skills. These are abilities and knowledge possessed or gained by a person to do a particular job or task (Motowidlo \& Kell, 2012; Robles, 2012). Learning skills requires practice and is always associated with psychomotor humans. It is impossible to learn a skill just by listening to someone talking, seeing a demonstration, or just reading a book without practicing (Elnaga \& Imran, 2013).

\section{Validity Test Module Improvement of self-awareness Excellent Service of Education Personnel}

\section{Expert Test Module Increasing self-awareness Excellent Service Educational Staff}

Product revision is carried out based on the results of the module feasibility test by experts. Data on the results of the feasibility test are compiled based on an assessment questionnaire filled by four experts. Data collection for the feasibility stage was carried out on February 6, 2017, until February 8, 2017. The results of the expert evaluation of all aspects of the instrument were collected and used as a reference in revising the products compiled. This made the formulation of modules suitable for use by the facilitators.

Table 2 presented the results of the expert feasibility test about the assessment of the Self-awareness Improvement Module Excellent Service of Education Personnel.

Table 2. Feasibility Test Results of Product Content by Experts

\begin{tabular}{lllll}
\hline No & Experts & Score & Percentage & Expert Opinion \\
\hline $\mathbf{1}$ & First Expert & 23 & 92 & Be accepted \\
$\mathbf{2}$ & Second Expert & 22 & 88 & Be accepted \\
$\mathbf{3}$ & Third Expert & 22 & 88 & Be accepted \\
$\mathbf{4}$ & Fourth Expert & 20 & 80 & Be accepted \\
& Total & & 87 & Be accepted \\
\hline
\end{tabular}

Based on Table 2, the module has high content feasibility since the four experts gave a positive response with an average of $87 \%$. Therefore, the module constructs can be used by facilitators to increase self-awareness of the excellent service of education personnel. 
The validity of the constants was calculated using the formula

$$
\frac{\text { Expert total score }}{\text { total }(25)} \times 100=\text { Content validity }
$$

The results of calculations based on the measured aspects are shown in table 3 .

Table 3. Results of The Feasibility Test of Product Content by Experts Based on Content

\begin{tabular}{|c|c|c|c|c|c|c|c|}
\hline \multirow[t]{2}{*}{ No } & \multirow[t]{2}{*}{ Statement } & \multicolumn{6}{|c|}{ Agreement } \\
\hline & & A.I\% & A.II\% & A.III\% & A.IV & Total & Judgment \\
\hline 1. & $\begin{array}{l}\text { Fill in the module according to the } \\
\text { target population }\end{array}$ & 100 & 100 & 100 & 80 & 95 & Be accepted \\
\hline 2. & $\begin{array}{l}\text { The module contents can be } \\
\text { implemented well later }\end{array}$ & 80 & 80 & 80 & 80 & 80 & Be accepted \\
\hline 3. & $\begin{array}{l}\text { Fill in the module according to the time } \\
\text { allocated }\end{array}$ & 100 & 80 & 80 & 80 & 85 & Be accepted \\
\hline 4. & $\begin{array}{l}\text { The contents of the module can be used } \\
\text { as information material to improve the } \\
\text { self-awareness of the excellent service of } \\
\text { education personnel }\end{array}$ & 80 & 100 & 80 & 80 & 85 & Be accepted \\
\hline 5. & $\begin{array}{l}\text { The contents of the module can be used } \\
\text { to help education personnel provide } \\
\text { excellent services to the targets. }\end{array}$ & 100 & 80 & 100 & 80 & 90 & Be accepted \\
\hline & Total & 92 & 88 & 88 & 80 & 87 & Be accepted \\
\hline
\end{tabular}

Based on the results of the calculations in Table 3, the average level of approval in item 1 shows that the design module increased self-awareness of excellent service educational staff. It is at a level feasible to be used by facilitators to increase trust, knowledge, and skills in offering excellent service by education personnel. The average level of approval in item 2 is considered feasible to be used by facilitators. The average level of approval in item 3 shows the module has been designed under the time required, which is feasible.

In item 4, the contents of the module information material increase the trust, knowledge, and skills of participants in conducting counseling services. Education staff services are $85 \%$ and therefore the module is approaching a feasible category. It can be used as information material to increase participants' trust, knowledge, and skills in conducting educational service counseling. The average level of approval in item 5 shows the module is suitable for use to increase the participants' trust, knowledge, and skills in conducting educational counseling services.

The expert's assessment of the product developed reached $87 \%$, showing it is in a workable assessment category. An open questionnaire provided data in the form of comments and suggestions from the four experts on the product developed. The four experts provide positive comments and suggestions, and therefore the research product is a Self-Awareness Improvement Module of Excellent Services Education Personnel tested and content-worthy.

Based on the results of the data at the feasibility test stage, the product was revised. Product revision activities aim to make improvements to improve the modules prepared based on the input from experts. The input is presented as (1) pay attention and check the writing of the material with correct and standard written procedures, (2) focus on the synchronization of contents (3) check systematics, plagiarism, writing/language, and EYD, (4) pay attention to writing synchronization, and (5) pay attention to the module steps.

The module is made as an improvement to be implemented at the usage test stage for the facilitator to see the use of the product. The research product produced in this study is the Self-Awareness Improvement Module of Excellent Services for Education Personnel. The results show that the modules compiled by experts have reached the feasible criteria. This is evidenced by the average value of the entire 
education personnel can be used for self-awareness, knowledge, and skills of Participants to provide excellent education services. The results of the feasibility test show that the module developed has fulfilled several characteristics. Also, the results of the experiment show that the self-awareness and skills of the participants related to the excellent service of the teaching staff increased after the training. This research recommends further testing of the effectiveness of the module for better results.

\section{References}

Anderson, T., \& Shattuck, J. (2012). Design-based research: A decade of progress in education research? Educational researcher, 41(1), 16-25.

Buchori, A., Setyosari, P., Dasna, I. W., Ulfa, S., Degeng, I. N. S., Sa'dijah, C., . . Karangtempel, S. T. (2017). Effectiveness of Direct Instruction Learning Strategy Assisted by Mobile Augmented Reality and Achievement Motivation on Students' Cognitive Learning Results. Asian Social Science, 13(9), 137-144.

Chow, G. M., \& Luzzeri, M. (2019). Post-Event Reflection: A Tool to Facilitate Self-Awareness, SelfMonitoring, and Self-Regulation in Athletes. Journal of Sport Psychology in Action, 1-13.

Danumiharja, M. (2014). Profesi Tenaga Kependidikan. Yogyakarta: Deepublish.

Daud, F. (2012). Pengaruh kecerdasan emosional (EQ) dan motivasi belajar terhadap hasil belajar Biologi siswa SMA 3 Negeri Kota Palopo. Jurnal Pendidikan dan Pembelajaran (JPP), 19(2), 243-255.

Day, D. V., Fleenor, J. W., Atwater, L. E., Sturm, R. E., \& McKee, R. A. (2014). Advances in leader and leadership development: A review of 25 years of research and theory. The leadership quarterly, 25(1), 63-82.

Edaran, S., SMK, D. P., Kurikulum, t. P., \& Kejuruan, P. M. (2015). Direktorat Jenderal Pendidikan Dasar dan Menengah.

Efendi, V. A. (2013). Pengaruh Faktor-Faktor Kecerdasan Emosional Pemimpin Terhadap Komitmen Organisasional Karyawan Di Universitas Kristen Petra. Agora, 1(1), 801-807.

Elnaga, A., \& Imran, A. (2013). The effect of training on employee performance. European Journal of Business and Management, 5(4), 137-147.

Gipps, C. (2002). Beyond testing: Towards a theory of educational assessment: Routledge.

Lestari, S. (2011). Strategi Pemasaran Sekolah di SMA Batik 1 Surakarta. Universitas Muhammadiyah Surakarta.

Mamulati, I., Triyuwono, I., \& Mulawarman, A. D. (2016). Fenomenologi Sumber Daya Manusia Sebagai Aset Intelektual Dalam Amal Usaha Muhammadiyah. Jurnal Akuntansi dan Investasi, 17(1), 93-103.

McDonough, J., \& McDonough, S. (2014). Research methods for English language teachers: Routledge.

Mead, R. (2017). Statistical methods in agriculture and experimental biology: Chapman and Hall/CRC.

Motowidlo, S. J., \& Kell, H. J. (2012). Job performance. Handbook of Psychology, Second Edition, 12.

Nguyen, J., Moorhouse, M., Curbow, B., Christie, J., Walsh-Childers, K., \& Islam, S. (2016). Construct validity of the eHealth literacy scale (eHEALS) among two adult populations: a Rasch analysis. JMIR public health and surveillance, 2(1).

Ningrum, E. (2016). Pengembangan Sumber Daya Manusia Bidang Pendidikan. Jurnal Geografi Gea, 9(1).

Prastika, N. D. (2016). Emosi positif pada perawat di rumah sakit umum daerah abdoel wahab sjahranie Samarinda. Paper presented at the Seminar Asean Second Psychology \& Humanity.

Pricila, A., Ulfah, M., \& Basri, M. (2013). Pengaruh Pergaulan Teman Sebaya Terhadap Rasionalitas Ekonomi Mahasiswa Pendidikan Ekonomi FKIP Untan. Jurnal Pendidikan dan Pembelajaran, 2(3).

Rahman, T. (2010). Studi pengembangan kualitas pendidik dan tenaga kependidikan melalui pendidikan dan pelatihan di MA Darun Najah Ngemplak Pati. IAIN Walisongo.

Rahmasari, L. (2016). Pengaruh Kecerdasan Intelektual, Kecerdasan Emosi dan Kecerdasan Spiritual Terhadap Kinerja Karyawan. Majalah Ilmiah Informatika, 3(1).

Richey, R. C., \& Klein, J. D. (2014). Design and development research: Methods, strategies, and issues: Routledge.

Rifani, R. (2016). Dinamika Emosi Pada Orang dengan HIV AIDS (ODHA)(Studi Kasus di Kota Banjarmasin.

Robles, M. M. (2012). Executive perceptions of the top 10 soft skills needed in today's workplace. Business Communication Quarterly, 75(4), 453-465.

Rustanto, A. E. (2017). Kepercayaan diri dan efikasi diri terhadap kematangan karir mahasiswa di politeknik LP3I Jakarta Kampus Jakarta Utara. Jurnal Lentera Bisnis, 5(2), 1-11. 
Rusuliana, D. (2015). Hubungan antara kecerdasan emosional dengan interaksi sosial siswa SMK Muhammadiyah 2 Sumberrejo Bojonegoro. UIN Sunan Ampel Surabaya.

Septiana, N. Z. (2016). Pelatihan Ketepatan Empati dengan Menggunakan Model Experiential Learning untuk Siswa SMK Jurusan Keperawatan. Didaktika Religia, 4(1), 241-267.

Septiana, R. (2013). Pengaruh Kepemimpinan Kepala Sekolah dan Motivasi Kerja Terhadap Kinerja Guru SMP Negeri Wonosari.

Sholeh, K. (2013). Pengembangan Teks Materi Pembelajaran Bahasa Indonesia Dalam Buku Ajar Berbasis Multiple Intelligences Dalam Kurikulum 2013.

Supriyanto, A. S., \& Troena, E. A. (2012). Pengaruh Kecerdasan Emosional dan Kecerdasan Spiritual terhadap Kepemimpinan Transformasional, Kepuasan Kerja dan Kinerja Manajer (Studi di Bank Syari'ah Kota Malang)‘. Jurnal Aplikasi Manajemen, 10(4), 693-617.

Susongko, P. (2016). Validation of science achievement test with the rasch model. Jurnal Pendidikan IPA Indonesia, 5(2), 268-277.

Taufik, T., Ifdil, I., \& Netrawati, N. (2017). Pengembangan dan Validasi Ifdil \& Taufik Self Awareness Inventory (ITSAI) untuk Mengukur Self Awareness Tenaga Pendidik di Perguruan Tinggi. Padang: Universitas Negeri Padang.

Xu, H., \& Chan, J. K.-S. (2017). Developing Undergraduates' Self-management and Self-awareness Abilities Through Service-Learning Emerging Practices in Scholarship of Learning and Teaching in a Digital Era (pp. 171-187): Springer.

Yudhaningsih, R. (2011). Peningkatan efektivitas kerja melalui komitmen, perubahan dan budaya organisasi. Jurnal Pengembangan Humaniora, 11(1), 40-50.

Yuniani, A., \& Pamudji, S. (2010). Pengaruh Kecerdasan Emosional Terhadap Tingkat Pemahaman Akuntansi. Universitas Diponegoro. 